\title{
Preliminary Concentration of Skim Latex and Its Wastewater Use Plate Sheet Microfiltration
}

\author{
S. Danteravanich ${ }^{1^{*}}$, I. Chalermpong ${ }^{2}$, P. Sridang ${ }^{3}$ \& S. Winsunthorn ${ }^{4}$ \\ ${ }^{1,2 \& 4}$ Faculty of Science and Industrial Technology, Prince of Songkla University, Surat Thani Campus, Muang, \\ Surat Thani, 84100 Thailand \\ ${ }^{1}$ National Excellence Center for Environmental and Hazardous Waste Management-Satellite Center, Prince of \\ Songkla University, Hat Yai Campus, Hat Yai, Songkhla, 90112 Thailand \\ ${ }^{3}$ Department of Civil Engineering, Faculty of Engineering, Membrane Science and Technology Research Center \\ (MSTRC), Prince of Songkla University, Hat Yai Campus, Hat Yai, Songkhla, 90112 Thailand
}

\begin{abstract}
Skim latex is a by-product of the concentrated latex factory. In this study, plate sheet membrane and cross-flow microfiltration (MF) experiments on skim latex and its wastewater were carried out to initially identify the performance of membrane separation. The series of MF experiments were conducted by using a nitrocellulose plate sheet membrane with a pore size of $0.1 \mu \mathrm{m}$ and $0.45 \mu \mathrm{m}$ at the pressures driven at 0.5 and 1 bar. The skim latex, skim latex diluted with water and skim rubber wastewater were tested by membrane separation. Sodium dodecyl sulfate (SDS) and cationic polymer were also added to the skim latex and used to combine it with the membrane. The results implied that filtration of skim rubber wastewater with a $0.45 \mu \mathrm{m}$ membrane at 1 bar pressure gave the highest flux of $152.6 \mathrm{l} / \mathrm{m}^{2}$-hr while the skim latex gave the highest flux of only $1.4 \mathrm{l} / \mathrm{m}^{2}-\mathrm{hr}$. When SDS and cationic polymer at $8 \mathrm{mg} / \mathrm{l}$ were added to the skim latex and tested, the highest flux was observed to increase as 2.1 and $2.8 \mathrm{l} / \mathrm{m}^{2}-\mathrm{hr}$, respectively. When skim latex diluted with 5 and 10 times the amount of water was tested, the highest flux was determined to be 13.9 and $20.8 \mathrm{l} / \mathrm{m}^{2}$-hr, respectively. Using MF to filtrate the skim latex gave $48 \% \mathrm{SCOD}$ removal. This result reflects that the MF system might be an alternative technology applied in the concentrated latex factory, especially to the rubber skim process.
\end{abstract}

Keywords: Skim latex, microfiltration, plate sheet, wastewater

\subsection{INTRODUCTION}

Thailand started to grow rubber trees a century ago. The rubber industry was developed gradually, but especially during the last three decades of the intensive replanting program, which highly increased natural rubber production. Centrifugation is widely used in the concentrated latex produced in Thailand. Centrifugation produces skim latex as a by-product. Skim latex is

\footnotetext{
* Correspondence to: S. Danteravanich (email: somtip.d@psu. ac.th)
}

composed of $4-5 \%$ of dry rubber contents (DRC) and bioactive materials called latex serum containing a large fraction of proteins. Skim rubber is defined as the rubber produced from skim latex. Coagulation of skim latex can be either spontaneous or by treatment with sulphuric acid that leaves the serum portion contaminated with the acid which becomes wastewater. This promotes hydrogen sulphide gas in the anaerobic effluent ponds causing a foul smell. In addition, with acid coagulation, the acid content in the coagulated rubber reduces its quality and shows some tendency to scorch [1]. 
Membrane technology can be considered when separation, purification or concentration processes are needed. This technology is rather new but is developing very fast in many fields. It permits very specific applications. It can also replace or improve classical processes such as evaporation [2]. Membrane application in wastewater/by-product recovery and treatment is also gaining significant popularity. Selection of right membrane and filtration technique is an important consideration to ensure a successful system development and long term performance [3].

Membrane can be seen as a kind of filter separating particles from a fluid. The family of liquid-phase pressure- driven processes, microfiltration (MF), ultrafiltration (UF) and reverse osmosis (RO) can be used to separate micron and sub-micron species in industrial processes, streams and effluents. The pore size of membrane used for microfiltration and ultrafiltration are in the ranges of 0.1-2 micron and 0.01-0.1 micron, respectively. The membranes used for ultafiltration (UF) are finely micro filtration (UF) are finely microporous, and in most cases they are asymmetric. Water transport is by viscous flow through the pores, driven by a moderate applied pressure. Small solutes may also pass through the membranes, but macrosolutes, colloids, and some charged species are retained. While microfiltration is an extension of UF, the me mianes have a larger pore size. of UF, the membranes have a larger pore size. Microsolutes are passed, but large colloids and micron-sized particles such as cells are retained. Transport of solvent and solute through the membranes occurs by convective flow through the micropores. This convective transport is pressuredriven.

Membrane technology is relatively new to rubber industry application and has many prospects for being developed further. Studies on ultrafiltration with a plate-and-frame unit and a tubular membrane system of epoxidised natural rubber (ENR) latex showed that concentration levels between 60 and $65 \%$ of total solids could be routinely achieved. It was shown that the ultrafiltration of ENR latex conforms to the general theory of the unit operation on biological feed streams [4]. The concentration of field latex using a tubular cross flow ultrafiltration system, one of the pressure-driven membrane separation echniques, was reported by Veerasamy and team in 2003 [5]. Results implied that field latex with a suitable composite preservation system $(1.0 \%$ ammonia, $0.1 \%$ ammonium laurate and $0.025 \%$ TMTD/zinc oxide) could be concentrated from DRC to $46 \%$ DRC, by applying a cleaningin-place technique with a transmembrane pressure of 2.5 bar. Novalic and team studied the ross-flow filtration of latex emulsion on a pilot scale using organic and inorganic membranes with different cut-off values. The aim of the project was to increase the concentration of 1 wt $\%$ styrene butadiene latex emulsion resulting from industrial production using cross-flow iltration, and to investigate the process performance using different types of membranes. The permeate flux lay in the range of $0.14 \times 10^{-5}$ to $2.36 \times 10^{-5} \mathrm{~ms}^{-1}$ when the emulsion was concentrated up to about $40 \mathrm{wt} \%$. Although three different membrane types, one orgaic and two norganic, with varying cut-off values $(20000$, 50000 and 0.2 micron) were used, no significant ifferences in average permeate flow were observed. The concentration of the latex emulsion was seen to have the greatest effect on the permeate flux, and with increasing concentration, the flux was observed to drop to about zero. contrast to this, during continuous testing over period of nearly two months, using two emulsions of $15 \mathrm{wt} \%$ and $1 \mathrm{wt} \%$, respectively, the permeate flow rate remained practically stable [6]. In addition, the investigation of ultrafiltration and microfiltration membranes in latex purification by diafiltration with suction was reported by Tishchenko and team in 2002. Operating conditions of diafiltration with suction in purification of poly(glycidyl) methacrylate latex from sodium tetraborate and emulsifier were studied in a batch process using ultrafiltration blend polysulfone/poly(vinylpyrrolidone) and microfiltration Synpor membrane. It was shown obtained by 8 h-suction diafiltration with the Synpor membrane having a pore entrance size close to nanoparticle diamensions [7]. Fo skim latex concentration by membranes, it was found that Paiboon and team studied it using ultrafiltration in 2005. Operating parameters such as the cross flow rate and pressures were done in the university laboratory on the day of investigated. It was shown that polysulfone 0.1 sampling.

micron membrane operating with a cross flow at a pressure of 50 psi was the most suifa nost suitable but ot worthwhile economically. A separation of $63.3 \%$ was obtained. Cleaning with $0.2 \% \mathrm{NaOH}$ $(\mathrm{w} / \mathrm{w})$ solution was effective and reduced the total resistance of $90.94 \mathrm{kPa} /\left(\mathrm{l} / \mathrm{m}^{2} \mathrm{~h}\right)$ to $0.14 \%$ of the total resistance. The other methods or new membrane types for separation of water from skim latex should be further investigated [8]

Since skim latex is obtained along with the concentrated rubber latex during centrifugation of the field rubber latex, proteins and the other non-rubber constituents which have specific gravities higher than that of the rubber also migrate into the skim fraction during centrifugation and not only reduce the quality of the Thecess. The usual method fis done by coagulation with sulphuric acid. This process could affect the environment as mentioned above. In order to avoid pollution, and to investigate potential recovery application to skim latex and its wastewater, a preliminary examination of membrane technology of cross-flow microfiltration for such samples was conducted with several series of batch tests. This paper illustrates the test results.

\subsection{MATERIALS AND METHODS}

2.1 Skim Latex and its Wastewater Characteristics Determination

Skim latex and its wastewater samples were taken from 6 concentrated latex factories in Surat Thani province in Southern Thailand. Grab sampling of each skim latex sample as well as its wastewater from the concentrated latex factories was undertaken. A total of 12 samples were collected for physical and chemical analysis. The temperature and $\mathrm{pH}$ were determined on site. The analysis of $\mathrm{pH}, \mathrm{COD}, \mathrm{BOD}_{5}$, suspended solids, TDS, TS, Org-N, $\mathrm{NH}_{3}-\mathrm{N}$, TKN, TP and $\mathrm{Mg}$ of the samples were conducted according to the procedures described by APHA, AWWA \& WEF in 1992 [9]. The chemical analysis was

\subsection{Microfiltration Experiment}

In this study, skim latex, skim latex diluted with water and skim rubber wastewater were tested by membrane separation of microfiltration. Natural latex does not contain only rubber hydrocarbon. The other components, not hydrocarbon, contents" are lipids, proteins, amino acids, inositols, carbohydrate and trace elements contained in the latex. Some of these non rubber contents are either dissolved or suspended in the aqueous medium of the latex while the others are adsorbed on the surface of the rubber particles [10] Although, the field latex passed the centrifugation process, the non rubber contents still remained in the serum of skim latex. If the skim latex was diluted with water, the concentrations of non-rubber constituents in the skim latex were decreased. In addition, if the diluted skim latex is separated from the membrane, the non rubber contents in the concentrated skim latex obtained are washed out and promote the purification of skim rubber. Based on this reason, the skim latex diluted with water was investigated in this study. Moreover, skim rubber wastewater was also examined. The skim rubber wastewater contained most of the serum from the field rubber latex. Testing of skim ubber wastewater using the MF process aims to nvestigate whether the non-rubber contents and a fine rubber particle from the rubber latex affect the MF process.

In this study, nine sets of batch experiments or determining the permeation flux of cross-flow microfiltration applied to skim latex and its were carried out. The filtration process was studied in the lab scale unit and its scheme is shown in Figure 1. The nitrocellulose plate sheet membrane with a pore size of $0.1 \mu \mathrm{m}$ and 0.45 $\mu \mathrm{m}$ at the pressure-drive of 0.5 and 1 bar were investigated. Since the initial test of skim latex a results, then the investigation of the skim latex 


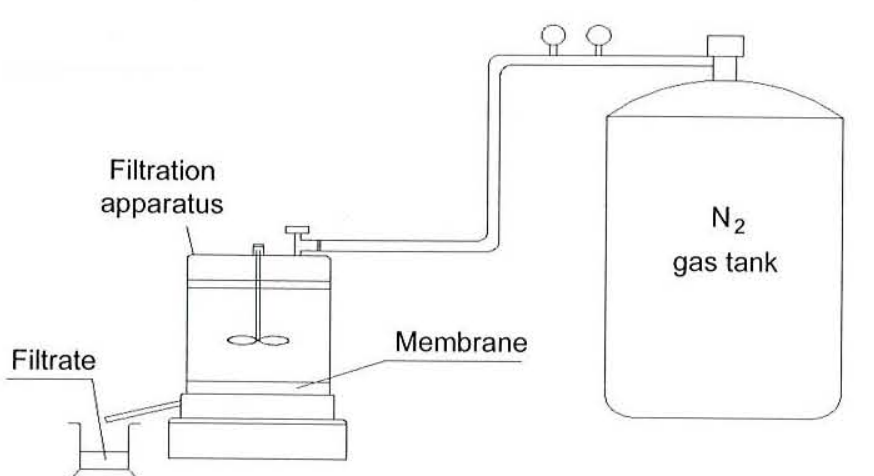

Figure 1 Process scheme of the experimental unit of cross-flow microfiltration

was conducted with only a high pressure of 1 bar and $0.45 \mu \mathrm{m}$ membrane. The series of MF experiments were conducted by testing with skim latex, skim latex diluted with water and skim rubber wastewater. SDS and cationic polymer were also added to the skim latex and used combine with the membran polymer were used in order to condition the slim latex. Table 1 illustrates the test conditions investigated in this study. Before filtration, the samples were determined for $\mathrm{pH}, \mathrm{SCOD}, \mathrm{BOD}_{5}$. SS, TDS, TN and TP. During filtration times of $5,10,15,20,30,40,50,60,80,100$ and 120 minutes, filtrate was quantified and calculated for flux values. After that, the filtrate samples were taken and analyzed for $\mathrm{pH}, \mathrm{SCOD}, \mathrm{BOD}_{5}$

Table 1 Cross-flow MF testing conditions

\begin{tabular}{lcccl}
\hline Test No. & samples & $\begin{array}{c}\text { Condition } \\
\text { Pressure } \\
(\mathbf{b a r})\end{array}$ & $\begin{array}{c}\text { Pore size of } \\
\text { membrane }(\boldsymbol{\mu m} \mathbf{m})\end{array}$ & Chemical used/dilution \\
\hline 1 & & 0.5 & 0.1 & No chemical added \\
2 & Skim latex & 0.5 & 0.45 & No chemical added \\
3 & wastewater & 1.0 & 0.1 & No chemical added \\
4 & & 1.0 & 0.45 & No chemical added \\
5 & Skim latex & 1.0 & 0.45 & $8 \mathrm{mg} / \mathrm{l}$ SDS \\
6 & & 1.0 & 0.45 & $8 \mathrm{mg} / \mathrm{l}$ Polymer cationic \\
7 & & 1.0 & 0.45 & Skim latex: distilled water $=1: 5$ \\
8 & & 1.0 & 0.45 & Skim latex: distilled water $=1: 10$ \\
9 & & 1.0 & 0.45 & No chemical added \\
\hline
\end{tabular}

Table 2 Skim latex and its wastewater characteristics

\begin{tabular}{|c|c|c|c|c|}
\hline \multirow[t]{2}{*}{ Parameters } & \multicolumn{2}{|c|}{ Skim latex } & \multicolumn{2}{|c|}{ Skim rubber wastewate } \\
\hline & range & average & range & average \\
\hline $\mathrm{pH}$ & $9.39-10.0$ & 9.58 & $2.82-5.15$ & 4.10 \\
\hline SS, (mg/l) & $1,000-4,200$ & 2,473 & $300-1,320$ & 787 \\
\hline TDS, (mg/l) & $10,720-85,000$ & 53,827 & $4,700-64,360$ & 29,905 \\
\hline $\mathrm{TS},(\mathrm{mg} / \mathrm{l})$ & $12,200-86,000$ & 56,300 & $5,000-65,620$ & 30,692 \\
\hline $\mathrm{COD},(\mathrm{mg} / \mathrm{l})$ & $83,283-288,288$ & 195,395 & $11,022-26,052$ & 20,206 \\
\hline BOD, $(\mathrm{mg} / \mathrm{l})$ & $12,568-29,313$ & 17,198 & $9,116-16,410$ & 12,513 \\
\hline $\mathrm{NH}_{3}-\mathrm{N},(\mathrm{mg} / \mathrm{l})$ & $1,736-3,461$ & 2,500 & $406-2,834$ & 1,698 \\
\hline Org-N, (mg/l) & $372-3,441$ & 1,000 & $50-2,075$ & 634 \\
\hline TKN, (mg/l) & $2,206-5,900$ & 3,573 & $456-3,458$ & 2,331 \\
\hline TP, (mg/l) & $12.76-41.99$ & 20 & $3.16-32.57$ & 15 \\
\hline $\mathrm{Mg},(\mathrm{mg} / \mathrm{l})$ & $2,021-2,670$ & 2,341 & $144-2,449$ & 1,147 \\
\hline
\end{tabular}

in the process, this contributed to the skim latex being alkaline. However, the skim rubber wastewater was acidic due to sulphuric acid addition for coagulation. The concentrations of suspended solids, TDS and TS of the skim latex were observed to be 2-3 times higher than in skim rubber wastewater. A large amount of ammonia in the skim latex and its wastewater was determined, mainly attributed to the addition of ammonia in the production process. In addition, the concentration of organic nitrogen in the skim latex and its wastewater was determined to be higher than $2,000 \mathrm{mg} / \mathrm{l}$. This was because the skim latex and its wastewater contained mainly serum. Serum is a liquid media of rubber latex. It contains non-isoprene compounds or non rubber contents which are lipids, proteins, amino acids, inositols, carbohydrate and trace elements [10]. Based on the data obtained, it was apparent that the skim latex and its wastewater were very rich in organic matter, ammonia, organic nitrogen, SS, TDS, and Mg. The concentrations of such elements in the skim latex were found to be higher than in the skim rubber wastewater. These skim ubber wastewater characteristics were consistent with Prabnakorn's study in 2000. It was reported that the average concentrations of COD, BOD, $\mathrm{SS}$ and $\mathrm{pH}$ of the skim rubber wastewater were $12,367 \mathrm{mg} / \mathrm{l}, 9,600 \mathrm{mg} / \mathrm{l}, 794 \mathrm{mg} / \mathrm{l}$, and 3.82 , respectively [11].

\section{The Experimental MF Results}

The performance of MF for 2 hours was shown in Figure 2. The permeate flux values implied that filtration of the skim latex wastewater with 0.45 um membrane and 1 bar pressure gave the highest flux of $152.6 \mathrm{l} / \mathrm{m}^{2}$-hr while the skim latex gave the highest flux of only $1.4 \mathrm{l} / \mathrm{m}^{2}$-hr, 10 times ower than in the filtration of the skim latex wastewater. When SDS and cationic polymer at $8 \mathrm{mg} / \mathrm{l}$ were added in the skim latex, the highest flux was observed to increase at 2.1 and $2.8 \mathrm{l} / \mathrm{m}^{2}-\mathrm{hr}$, respectively.

The addition of SDS and cationic polymer to skim latex could affect skim latex conditioning. Since latex particles comprise mainly of hydrocarbon, water and a minor amount of protein and lipid, the surface of a latex particle is coated with a thin layer of hydrated protein. It is quite reasonable to believe that the hydrated quite reasonable th latex suspension. Surface charge on a hydrated protein layer of the latex particle is controlled mostly by dissociation of carboxyl and amino groups. Thus the net charge on the surface of hydrated protein layer is determined by concentration of negative carboxyl ions and positive amine ions. In a latex suspension, the positex repulsion among similar charged particles keeps the latex particles from coming close to each other 


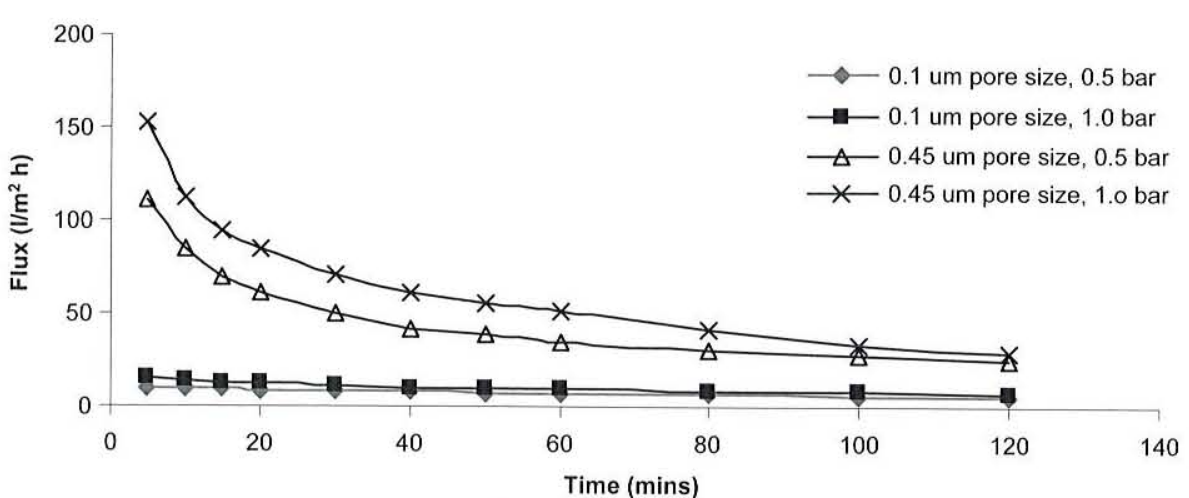$$
25
$$

(a) Test of skim rubber

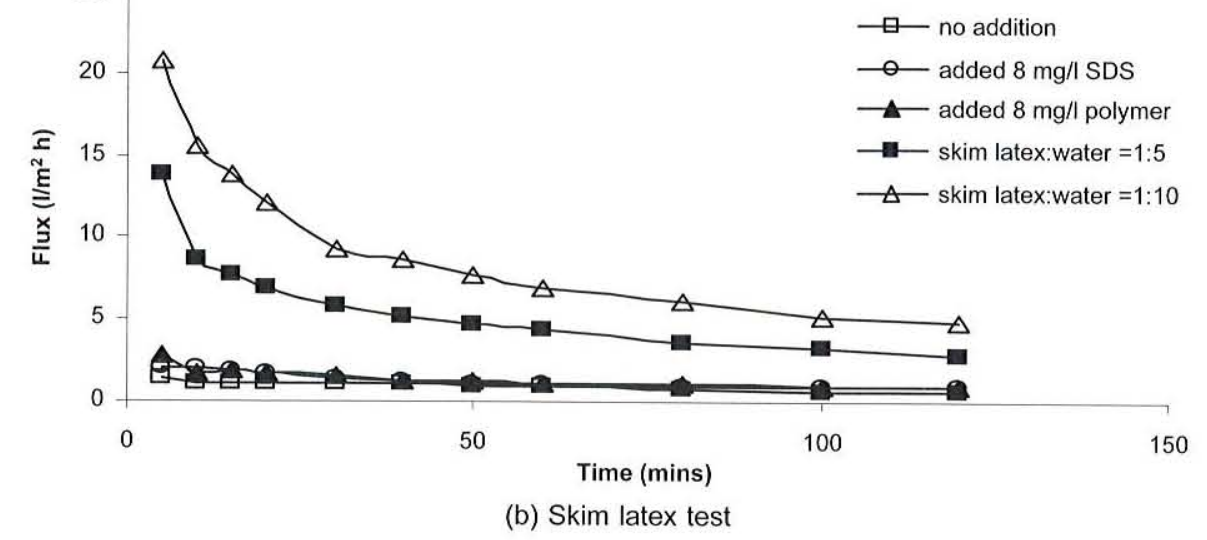

Figure 2 Performance of flux observed when used cross-flow MF for skim latex and its wastewater

[12]. The rubber particles in the skim latex are fine particulates. Thus the conditioning of fine latex particles in the skim latex can be considered when SDS and cationic polymer are added. SDS is an anionic surfactant that can enhance the greater dispersion of latex particles and help the particles to stay in the suspension due to high diffusional movement. The cationic polymer can be adsorbed on solid surfaces by means of one o more of the following: electrostatic charge attraction, hydrogen bonding, covalent bonding and hydrophobic interactions [13], [14] Introduction of cationic polymer seems to act as a coagulant for the latex. In addition, the $\mathrm{pH}$ of the skim latex after addition of such two chemicals was observed not to differ much from the skim latex without chemical addition. However, the $\mathrm{pH}$ of the filtrate from the skim latex with SDS and cationic polymer $(\mathrm{pH}$ of 9.46 and 9.56) added was determined to be higher than the filtrate from the skim latex without chemicals addition ( $\mathrm{pH}$ of 9.30). This reflected that the addition of these two chemicals in the skim latex could affect membrane filtering caused by skim mechanisn this result needs to be investigated further

When the skim latex diluted with 5 and 10 times water was tested, the highest flux was determined to be 13.9 and $20.81 / \mathrm{m}^{2}-\mathrm{hr}$ respectively. These values increased more than 10 and 20 times when compared with the tes without chemical addition in the skim tat the flux obtain was increased. This finding on the flux effect is consistent with Paiboon and team's study in 2005. They demonstrated that using $0.1 \mu \mathrm{m}$ polysulfone membrane at $50 \mathrm{psi}$ to separate the skim latex gave a permeate flux of $3.02 \mathrm{l} / \mathrm{m}^{2}$.h. When the $0.1 \mu \mathrm{m}$ polyacrylonitrite membrane was

Table 3 Reduction of TS, SCOD, and TP when MF was applied

Test set

im latex : No chemical added, $0.45 \mu \mathrm{m}, 1.0 \mathrm{bar}$

Skim latex : $8 \mathrm{mg} / \mathrm{l}$ SDS added, $0.45 \mu \mathrm{m}, 1.0 \mathrm{bar}$

Skim latex : $8 \mathrm{mg} / \mathrm{l}$ polymer added, $0.45 \mu \mathrm{m}, 1.0 \mathrm{bar}$

Skim latex : $1: 5$ with water, $0.45 \mu \mathrm{m}, 1.0 \mathrm{bar}$

Skim latex : $1: 10$ with water, $0.45 \mu \mathrm{m}, 1.0 \mathrm{bar}$

Skim rubber wastewater, $0.1 \mu \mathrm{m}, 0.5 \mathrm{bar}$

Skim rubber wastewater, $0.45 \mu \mathrm{m}, 0.5 \mathrm{bar}$

Skim rubber wastewater, $0.1 \mu \mathrm{m}, 1.0 \mathrm{bar}$

Skim rubber wastewater, $0.45 \mu \mathrm{m}, 1.0 \mathrm{bar}$

used at a pressure of 60 and $75 \mathrm{psi}$, the flux was observed to be $1.62 \mathrm{l} / \mathrm{m}^{2}-\mathrm{h}$ and $2.91 \mathrm{l} / \mathrm{m}^{2}-\mathrm{h}$, respectively [8].

In this study, the characteristics of latex on membrane surface were not investigated. However, the skim latex and its wastewater before filtration were examined and found to have chemical characteristics as follows. The $\mathrm{pH}$ and concentrations of SS, TDS, TS, COD, TKN, and TP of the skim latex were $10.17,7,740 \mathrm{mg} / \mathrm{l}$, $77,340 \mathrm{mg} / \mathrm{l}, 85,080 \mathrm{mg} / \mathrm{l}, 37,752 \mathrm{mg} / \mathrm{l}, 3,791 \mathrm{mg} /$ 1 and $90.06 \mathrm{mg} / \mathrm{l}$, respectively, while the skim rubber wastewater was $4.44,692 \mathrm{mg} / \mathrm{l}, 43,424 \mathrm{mg} /$ $1,44,126 \mathrm{mg} / \mathrm{l}, 29,921 \mathrm{mg} / \mathrm{l}, 3,570 \mathrm{mg} / \mathrm{l}$, and 26.63 $\mathrm{mg} / \mathrm{l}$, respectively. After MF was applied to the skim latex and its wastewater, the $\mathrm{pH}$ and concentrations of SS, TSD, TS, COD, TKN, and $\mathrm{TP}$ were decreased. Table 3 illustrates the percent removal of TS, SCOD, and TP after filtering. Using MF for the skim latex and skim rubber wastewater with the same condition of membrane pore size and pressure applied gave $48 \%$ and $15 \%$ SCOD removal, respectively.

Based on the above preliminary investigated results, it reflected that MF technology might potentially have many new applications for the concentrated latex industry. It might be applied as an alternative of the skim latex recovery either as skim latex concentration or serum recovery as well as purification of skim latex and treatment of the skim latex wastewater. The precise evaluations of the optimum conditions of membrane separation of skim rubber and the characteristics of retentate and permeate were recommended to be further verified in order to be applied in the concentrated latex factory. In addition, the concept of hybrid microfiltration processes a ce the synergistic combination of membranes with another unit operation, such as coagulation, recommended to be further investigated for the skim latex process. Laboratory and batch scale experiments, and testing in a pilot plant are needed for more investigation.

\subsection{CONCLUSION}

This preliminary investigated result reflects that the cross-flow MF system could be an alternative technology applied in the concentrated latex factory, especially to the skim latex process. However, the further optimum conditions of membrane separation of skim rubber and the characteristics of retentate and permeate were recommended to be further verified in order to be applied to concentrated latex factory to make the processing environment-friendly and enhance the production of high value by-products from skim latex.

\section{REFERENCES}

[1] Naunton. 1961. The Applied Science of Rubber. The WJS ed. London: Arnold Edward. 
[2] Mora, J.C. 1992. Membrane Technology in Pulp and Paper Industry: General Consideration. Proceedings of National Seminar on Conventional and Advanced Techniques for Wastewater Treatment. 7-8 February. 1-11.

[3] Hasan, K.S., C. Visvanathan, P. Ariyamethee, S. Chantaraaumporn, and P. Moongkhumklang. 2002. Vibratory Shear Enhanced Membrane Process and Its Application in Starch Wastewater Recycle. Songklanakarin J. Sci. Technol. 24: 899-906.

[4] Nambiar, J. 1993. Concentration of Epoxidised NR Latex by Ultrafiltration. Proceedings in International Rubber Technology Conference. 111-124.

[5] Veerasamy, D., N.M. Sulaiman, J. Nambiar, and Y., Aziz. 2003. Concentration of NR Field Latex Using Tubular Cross Flow Ultrafiltration System. J. Rubb. Res. 6(1): 12-26.

[6] Novalic, S., G. Heisler, and J. Lahnsteiner. 1997. Cross-flow Filtration of Latex Emulsion on a Pilot Scale Using Organic and Inorganic Membranes with Different Cut-off Values. Journal of Membrane Science. 130: 1-5.

[7] Tishchenko, G., R. Hilke, W. Albrecht, J. Schauer, K. Luetzow, Z. Pientka, and M. Bleha. 2002. Ultrafiltration and Microfiltration Membranes in Latex Purification by Diafiltration with Suction. Separation and Purification Technology. 30: 57-68.

[8] Paiboon, I., V. Thonglib, and S. Genapong. 2005. Skim Latex Concentration by Membranes. Proceedings of The Engineering Conference of Prince of Songkla University. 8-9 December: ChE30-ChE-37.
[9] APHA, AWWA and WEF. 1992. Standard Methods for the Examination of Water and Wastewater. $18^{\text {th }}$ ed. New York: American Public Health Association.

[10] Visitnonthachai, D. 2004. Characterization of Non-isoprene Components and Their Effects on Mixing Properties of Unvulcanized Raw Natural Rubber. M.S. (Biochemistry) Thesis. Graduate School. Kasetsart University.

[11] Prabnakorn, P. 2000. Primary Treatment by Air Flotation in Rubber Trap Tank for Latex Rubber Plant Wastewater Treatment. M.S. of Science Thesis in Environmental Management, Prince of Songkla University.

[12] Buannual, P., N. Srisuwan, S. Arrykul, and S. Danteravanich. 1995. Treatment of Wastewater from a Rubber - Gloves Plant, Songkhla Province, Thailand. Manuscript for presentation in Thailand - Japan Joint Conference \& Exhibition on Solid - Fluid Separation Technology. Chulalongkorn University, Bangkok, Thailand. July 25 - 27.

[13] Linke, W.F., and R. B. Booth. 1960. Physical Aspects of Flocculation by Polymer. AIME Trans. 217: 364-371.

[14] Moudgil, B.M., and P. Somasundaran. 1984. Adsorption of Cationic Polyacrylamide on Hematite and Silica: Effect of Polymer-Sodium Dodecylsulfonate Interaction. In Fundamentals of Adsorption. United Engineering Trustees, Inc. 335-364.

[15] Inkaew, C., J. Chipakdee, S. Worakatamas, and A. Wongtong. 2006. Potential of Nutrients Recovery from Skim Creps Wastewater. Bachelor of Science Project. Faculty of Technology and Management. Prince of Songkla University. Surat Thani Campus. 